DR MARGIE COMRIE is an associate professor in communication studies at Massey University.

\section{Insider's view of nuclear-free NZ's 'people power'}

Peace, Power \& Politics: How New Zealand Became Nuclear Free, by Maire Leadbeater. Dunedin: Otago University Press, 2013, 344pp. , ISBN 9781877578588

TOURNALISM'S focus on major $\checkmark$ political figures and high level negotiations leaves the more diffuse activities of grassroots politics in the shadows. So it is refreshing to see a well-researched book unapologetically placing civic groups at centre-stage. Marie Leadbeater's thorough chronology of the last 40 years of New Zealand's peace movement and the fight for a nuclear free country fills some gaps in our knowledge about the mechanics of 'people power'. It's an insider's view. Leadbeater, daughter of feminist and peace campaigner Elsie Locke, says activism is in her genes. She was secretary and then spokeperson for Auckland's Campaign for Nuclear

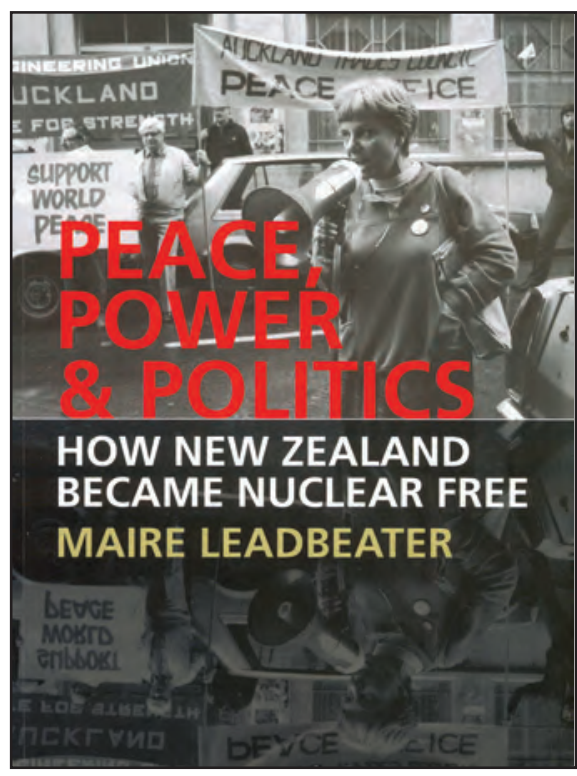

Disarmament, closely involved with the nuclear free protests of the 1970s and 1980s and still demonstrating at Waihopai's satellite communication monitoring station in 2013.

It is a large, dense book. Opening with the Pacific People's Charter and the 1975 Nuclear Free Pacific conference in Suva, Leadbeater moves swiftly to the more familiar story of Rowling's Labour government caught between American pressure to accept nuclear powered ships and its own Party's opposition. Subsequent chapters take us through Robert Muldoon's combative reign, the era of Peace Squadron sailboats confronting American submarines and destroyers, the 1985 Labour caucus decision to 
ban nuclear capable warships, detonation of the Rainbow Warrior and its repercussions, continuing protest opposing French nuclear testing at Moruroa, the first Gulf War and the ongoing opposition to satellite 'spy' bases in New Zealand.

The book is a valuable addition to David Robie's Rainbow Warrior saga, Eyes of Fire, and provides a counter-perspective to parts of David Lange's Nuclear Free the New Zealand Way, where Leadbeater seeks to reclaim kudos for the peace movement. She also makes effective use of Malcolm Templeton's revelations in Standing Upright Here, laying bare the manoeuvrings of foreign affairs and military officials and the extent of pressure applied by allies to halt anti-nuclear legislation. Her story is bolstered by interviews and carefully footnoted. While Leadbeater does tread familiar ground, her contribution is to pull the protest story together across the decades, consistently foregrounding peace movement efforts and achievements. She also demonstrates that, while change can be effected from below, it requires organisation and persistence possibly for decades.

Easily forgotten now is the sheer spread of the anti-nuclear movement. The book is a roll call of a wide number of groups - Christians for
Peace, Scientists Against Nuclear Arms, Matariki, Women Acting for Nuclear Disarmament, Engineers for Social Responsibility, Auckland Schools Against the Bomb and many more. Another element is the effective campaign in the early 1980s encouraging New Zealand's then numerous local bodies to proclaim 'nuclear free zones'. Along with supportive local government politicians, were a formidable bunch of Labour Party MPs and the ebullient Bob Jones and his New Zealand Party. The crusade also had union backing, at a time when unions packed a greater punch: maritime unions went on a week's strike while the Truxton was in Wellington; Auckland Harbour Board employees refused to staff tugs to dock the Texas. Leadbeater makes little mention of the media's role, but it is apparent the numerous protests received a level of coverage unlikely today and it is interesting to speculate to what extent the legitimacy afforded by widespread public support or the nature of the news media contributed to this.

The book also reminds us the nuclear free movement is very much a wider Pacific undertaking, born from the powerlessness of indigenous peoples in the face of nuclear testing. There is a chapter on Pacific grassroots movements and an appendix on Kanaky/New Caledonia. Leadbeater 
also pays tribute to the role of Māori activists, acknowledging the view that nuclear free issues are also about Aotearoa/New Zealand as a colonial country and touching on the tensions this perspective brought to the movement.

Leadbeater provides a notable record of the management behind the succession of marches, protests, stunts and lobbying activities of a long-term public campaign. Passions sustaining the action are brought alive by accompanying illustrations of more than 30 peace and protest posters. Contemporary cartoons and dozens of photographs also document the many protests, the most dramatic of which feature low flying navy helicopters harassing peace flotilla yachts with their downwash and a victorious protestor riding the paint splattered submarine Haddo.

Despite this, the book is not an easy read. Leadbeater provides a list of abbreviations, valuable for the reader wading through an array of acronyms denoting dozens of campaigning and defence organisations. A further useful anchor is the timeline. At times I longed for dramatic firsthand accounts of clashes on the picket lines and derring-do on the seas. I would have appreciated a perspective on current citizen peace initiatives and the role of the internet. But ultimately that is not Leadbeater's purpose; hers is a sober historical record from the peace movement perspective. It is also-in the wake of the Fukushima nuclear plant disaster, clandestine mass international electronic surveillance and the conduct of our own GCSB-a timely one.

\section{References}

Lange, D. (1990). Nuclear free the New Zealand way. Auckland, NZ: Penguin. Robie, D. (2005). Eyes of fire:The last voyage of the Rainbow Warrior [Memorial edition], Auckland, NZ: Asia Pacific Network.

Templeton, M. (2006). Standing upright here: New Zealand in the nuclear age 1945-1990. Wellington, NZ: Victoria University Press. 